K.S. Movchan

\title{
CONTROL SYSTEM OF UTILIZATION OF MEDICAL WASTE: EXPERIENCE OF THE EU AND RUSSIA
}

\author{
К.С. Мовчан
}

\section{СИСТЕМА УПРАВЛЕНИЯ УТИЛИЗАЦИЕЙ МЕДИЦИНСКИХ ОТХОДОВ: ОПЫТ ЕС И РОССИИ}

This article describes the European experience with medical waste processing, as well as presents an analysis of the current situation in this sphere in Russia. Description of the current changes in legislation is followed by the possible strategies for implementation of new methods and schemes in the field of medical waste. This topic is highly important nowadays because medical waste contains a variety of different hazardous and toxic elements that are dangerous for the environment and human health. Moreover, careless treatment of medical waste can affect people and especially children that can unknowingly interact with these objects especially with infectious materials remaining after usage in clinics and hospitals. The author proposes a special scheme for medical waste processing adopting the more sophisticated model of the «resource center» for a smaller scale, in particular, for medical waste. Based on this model it will be possible to improve the existing methods for waste management in this sphere as well as to develop new technologies that can improve environmental and economic aspects in this field.

ORGANIZATION OF MANAGEMENT; DEVELOPMENT STRATEGIES; ENVIRONMENT; MEDICAL WASTE MANAGEMENT; TECHNOLOGY MANAGEMENT.

Рассмотрен опыт европейских государств в сфере обращения с медицинскими отходами, а также приведен анализ текущей ситуации в данной сфере в России. Приводятся описание текущих изменений в законодательстве, а в качестве заключения - возможные пути решения и стратегии по внедрению новых методов в области обращения с медицинскими отходами. Эта тема сегодня очень актуальна, поскольку медицинские отходы содержат различные вредные и токсичные элементы, которые являются опасными для окружающей среды и здоровья человека. Неправильное обращение с медицинскими отходами может оказать негативный эффект на людей и, особенно, детей, которые могут по неосторожности взаимодействовать с данными отходами, особенно с инфекционными материалами, остающимися после использования в клиниках и больницах. Предложена специальная схема для обращения с медицинскими отходами на основании более сложной модели «ресурсного центра», но в меньших масштабах применительно для работы с медицинскими отходами. На основе данной модели можно будет усовершенствовать существующие методы управления отходами в данной сфере, а также разработать новые технологии, которые помогут справиться с экологическими и экономическими проблемами в этой области.

ОРГАНИЗАЦИЯ УПРАВЛЕНИЯ; СТРАТЕГИИ РАЗВИТИЯ; ОКРУЖАЮЩАЯ СРЕДА; МЕДИЦИНСКИЕ ОТХОДЫ; МЕТОДЫ УПРАВЛЕНИЯ; ТЕХНОЛОГИИ УПРАВЛЕНИЯ.

Introduction. Medical waste is generated as a result of actions related to the practice of medicine (including veterinary and dentistry) [6]. Infectious medical waste, according to experts, constitutes $15 \%$ of the waste stream. Many attempts to modernize the system of medical waste management are based solely on waste incineration or other technologies for eliminating waste. This approach has several weaknesses [1]. First, hospitals and other medical facilities are often unable to pay for waste disposal in a special waste incineration plant; as a result, waste of such institutions is either transported to landfill sites or has to be accepted free of charge. Second, many risks arise before the medical waste has reached the incinerator, and their negative impact on the environment is thus not reduced. Therefore, a more comprehensive and alternative strategy for the management of medical waste, involving minimization and segregation is needed. Introducing effective waste segregation systems and their classification based on the assessment of the real threat of infectious waste reduces the amount of medical waste by $3-5 \%$. 
The definition of medical waste. Medical waste, i.e., waste from hospitals and other medical facilities consists of two fractions, of which non-hazardous medical wastes typically constitute $75-90 \%$. This fraction is comparable to household waste, while the other hazardous medical waste includes all substances that can cause chemical, biological or physical injury. Hazardous medical waste, in turn, also can be divided into several categories: waste that could carry infection, pathological waste, used syringes, pharmaceutical waste, chemical waste and radioactive waste. These categories carry a much greater potential risk to human health than nonhazardous medical waste [2]. There is very little reliable numerical data on the possibility of transfer of contamination from hazardous medical waste to the medical staff or people dealing with such waste, and no data at all concerning the transfer of infection to the population of the surrounding areas. Another group is medical or pharmaceutical waste such as expired household medicines [14].

Environmental problems and risks associated with medical waste. Environmental issues of medical waste are attracting much attention in connection with the increase in the incidence of AIDS and hepatitis, as well as in connection with a potential negative environmental effect from the disposal of this waste in landfills or burning them. Incineration of medical waste releases gets a huge amount of toxic substances, including dioxins and furans, into the air. Incineration emissions also include heavy metals (lead, mercury and cadmium), fine dust, chlorides and other pollutants like products of incomplete combustion (PIC). The resulting combustion products are highly contaminated with ash, which is potentially dangerous for human health. It is scientifically proven that these pollutants can have a serious negative impact on the environment and on the health of people living near special incineration plants. In many countries, hazardous medical waste (needles, etc.) is not separated from the general flow of solid municipal waste, and it can increase the potential risk to the environment and the population living near landfills or other infrastructure for waste management [3]. People traditionally flush expired or unwanted prescribed medicines down the toilet or pour them down the drain. However, this method of disposing of medicines leads to immediate negative environmental effect.

It can cause pollution of sewage, which, in turn, adversely affects groundwater and surface water, fish and vegetation of bodies of water. When the water from these reservoirs is then used for household and drinking needs, it can cause a negative effect on the chemical compounds present in medicines.

EU legislation in the field of medical waste. Legal requirements of the Basel Convention concerning the transboundary movement of hazardous wastes are also applicable to medical waste. The countries that signed the Convention agreed with those principles regulating the transboundary movement of hazardous waste from countries that lack the infrastructure or control measures to allow safe disposal of such waste to those countries with the appropriate infrastructure and controls. Exported waste should be labelled in accordance with the recommended standards. EU Directive on the landfill of waste $(1999 / 31 / \mathrm{EC})$ prohibits disposal of infectious waste of hospitals and other health and veterinary authorities. The EU Directive on the incineration of waste $(2000 / 76 / E C)$ sets out specific limitations on the emission of toxic substance from medical waste incineration, the international Convention for the elimination of persistent organic pollutants (RORB) contains a list of plants for incineration of medical waste, which are among the major sources of dioxin in the environment [13].

The Protocol on persistent organic pollutants was signed by the European Community within the framework of the current EU legislation, setting the legal restrictions on the emission of dioxins and furans in the amount of $0.1 \mathrm{ng} / \mathrm{m}^{2}$, the toxic equivalent (TE) for installations burning more than 1 tonne of medical waste per hour, as a key principle of the Convention of the UN Economic Commission for Europe (UNECE) on the spread of air pollution in border areas. In 2000, the EU has introduced stricter limits on emissions of toxic substances from incineration of medical waste [4]. This has led to the shutdown of many plants for incineration of medical waste and has increased the number of enterprises for processing infectious health-care waste by other methods. 
However, the rate of introducing alternative means of processing medical waste is not quite large and incineration is still the predominant method in Europe. Although incineration is still widely used, other technologies are gaining popularity in Europe. Technologies other than incineration do not produce toxic dioxins and their introduction is consistent with the Stockholm Convention on persistent organic pollutants, which entered into force in May 2004. EU Directive Np2004/27/EU, modernising EU Directive Na2001/83/EC for human medicines, and EU Directive Np2004/28/EU, modernising EU Directive N2001/82/EC concerning veterinary medicines, have established that the environmental impact of drugs should be assessed and special arrangements to limit it should be considered [7].

Scheme of medical waste management in the EU. Eleven member-countries of the EU have systems for collecting medicines, allowing people to return unwanted medicines to the pharmacy. In 2002, only four countries had such a system: Austria, Greece, Ireland and the Netherlands. More than half of the European national systems were governed and funded by the pharmaceutical industry or by pharmacies, the rest is paid by municipalities. There are many differences between such schemes in various countries, including operational principles, funding mechanisms, and capabilities of the systems. In 2002, the European Federation of Pharmaceutical Industries and Association of Pharmacists conducted a review of the existing systems. The main results of the review revealed the following: return of medicines is fully managed and funded by a pharmaceutical network in 5 countries (Belgium, France, Luxembourg, Portugal and Spain). At the same time, pharmacists are involved in the management of such systems, together with private or public contractors in 6 countries (Denmark, Finland, Germany, Italy, Sweden and the UK) [8]. For example, Danish pharmaceutical waste must be deposited at distributed pharmacies. From these collection points, waste is directed to one of the municipal collecting stations, where a final sorting is made before shipment to Kommunekemi (approximately 50\%), which is jointly administered by the municipalities, for destruction, neutralization, or storage.
The system can consist of a network of pharmacies, then all the costs are distributed between pharmacies, wholesalers and industry according to their role in the distribution system. The industry is paying for the external costs (mostly incineration), with the exception of Luxembourg, where the pharmaceutical industry does not exist and the Ministry of Environment bears the cost. The system can be controlled by pharmacies and funded by municipalities (Finland, Italy and the UK), or by pharmacists according to the law of producer responsibility (Denmark and Sweden), or only industry (Germany, where manufacturers are required to defer costs associated with the recycling of packaging waste). The system's capabilities are usually limited to expired and unused medicines when the system is financed by pharmacies or municipalities. The industry of these countries should implement the principle of producer responsibility enshrined in national regulations and in the Directive on packaging waste. The system's capabilities for receiving subsidies include packaging (boxes, packages, etc.). The actions are controlled by associations of manufacturers, pharmacies and wholesalers, which have gained a good reputation in countries where the system of reception controls the entire pharmaceutical network. There are no such contact networks in other countries with the exception of the UK where the Association of the British Pharmaceutical Industry (ABP1) supports the existing systems in pharmacies and looks for ways to encourage patients to use such schemes of medical waste disposal [12]. No contacts are scheduled in new EU members because the receiving system operates without funding from the industry. Contacts with national environmental authorities took place in 5 countries, where the return of medicines is funded by the pharmaceutical industry (Belgium, France, Germany, Portugal and Spain), as well as in three other countries (Finland, Luxembourg and the UK). This often leads to the inclusion of the medicine return systems in the closed policy on waste management. Lack of contacts means that the methods for solving the problem are the responsibility of pharmacies for the operation of the systems of medicine return and reflect a lack of relevant legislation in the field of medical waste management. The 
European Federation of Pharmaceutical Industries and Association of pharmacists supports the creation of systems for return of expired and unused medicines in the EU, and if possible, the policy on waste management. It has yielded results and these systems operate in pharmacies, serving more than $90 \%$ of European consumers. Voluntary policies to promote the medicine return systems involve the development of such systems in countries where they already operate, and cooperation with the national pharmaceutical industry to promote cleaner production, depending on the national policy of waste management [9]. For example, in the Netherlands, special return systems of medicines through pharmacies are no longer needed due to the fact that waste is utilized via modern technologies after it is by consumers. The main conclusion of this section: the return of medicines works in many EU countries. These systems mainly differ by their capabilities for receiving expired and unused medications or stimulating the consumer to return the packaging, and are dependent on funding from the pharmaceutical industry

Legal regulation on the processing of medical waste in Russia. In accordance with paragraph 1 of article 49 of Federal law no. 323, medical waste includes all types of waste, including anatomical, pathological-anatomical, biochemical, microbiological and physiological waste generated through medical and pharmaceutical activity, manufacturing medicinal products and medical devices, as well as using activators of infectious diseases and genetically modified organisms for medical purposes.

Paragraph 3 of article 49 of Federal law no. 323-FZ determined that medical waste is subject to collection, use, disposal, placement, storage, transportation, accounting and disposal in a manner prescribed by the legislation in the field of ensuring sanitary and epidemiological welfare of the population [11].

In accordance with the legislation on sanitary and epidemiological welfare of the population, the issues of medical waste management are regulated by SanPiN 2.1.7.2790-10.

According to paragraph 1.2 of SanPiN 2.1.7.2790-10, mandatory sanitary and epidemiological requirements are imposed on:

- handling (collection, interim storage, decontamination, disposal, and transportation) of waste generated in organizations during medical or pharmaceutical activities, or therapeutic, diagnostic and recreational services (referred to as medical waste);

- location, equipment and operation of the facility for handling of medical waste;

- sanitary and anti-epidemic regime of work when handling medical waste.

Federal law determines the classification of medical waste according to its epidemiological, toxicological, radiation hazard, and also negative impact on the environment by hazard class $(\mathrm{A}-\mathrm{D})$ :

- class A - epidemiologically safe waste with composition similar to municipal solid waste;

- class B - epidemiologically hazardous waste;

- class - extremely epidemiologically hazardous waste;

- class G - toxicologically hazardous waste that belongs to $1-4$ class of danger;

- class D - radioactive waste.

However, the legal foundations of waste production and consumption for preventing harmful impact of waste production and consumption on human health and the environment established by Federal law No. 89 is still under development and will include some additions by the end of 2016 .

Possible solutions. One of the possible solutions for the topic of medical waste can be creating a special center for medical waste processing. This organization could be part of the system working with all types of waste generated in a certain area [5]. Though the processing of medical waste has a lot of special procedures, most of them concerned with potentially hazardous and dangerous waste, creating the above-described center for processing this type of waste would be a good way to minimize the environmental pollution.

Creation of the special center for medical waste treatment could solve the existing problems that are appearing in this sphere such as :

- disinfection of household equipment and medical equipment waste is often performed with obsolete methods which are difficult to control and not efficient in epidemiological terms;

- most loading and unloading, transportation within departments, buildings, and constructions, and delivery of waste to local waste containers outside of buildings is done manually; 


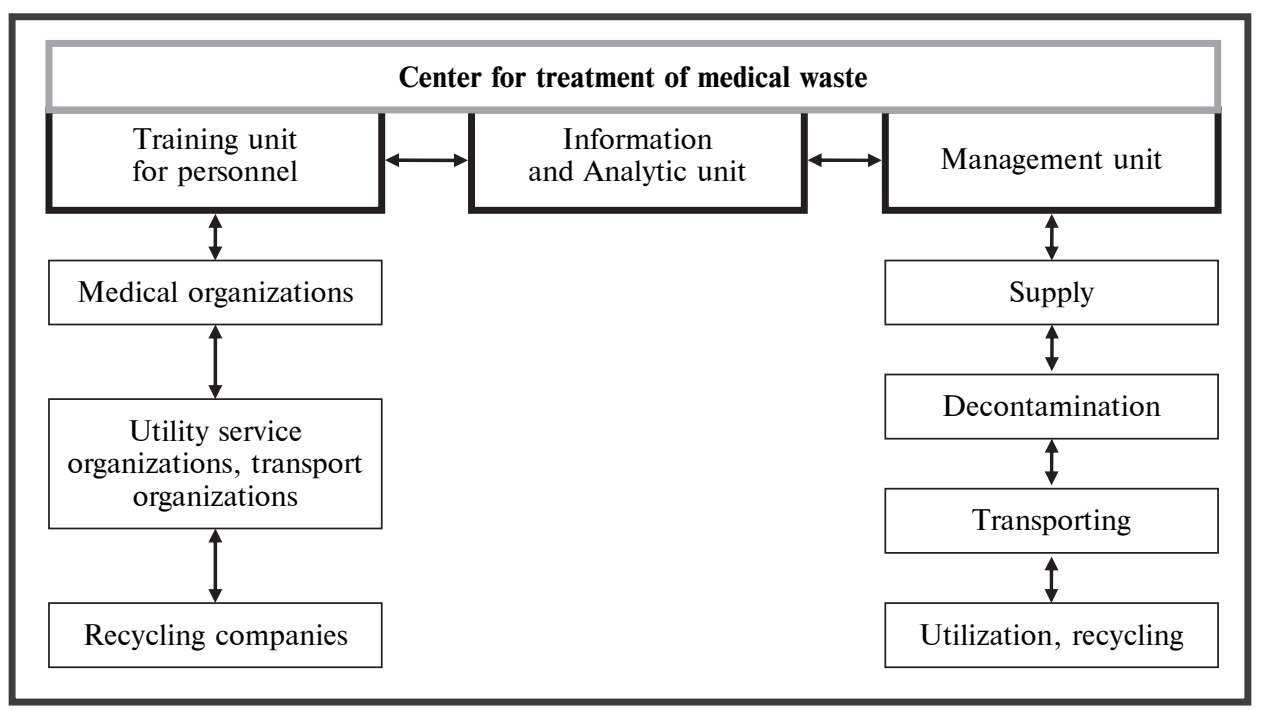

Center for medical waste processing

- current system of irremovable containers without liners and collection of garbage trucks has an outdated design, which causes loss of waste fractions during processing and transportation;

- special waste and household waste is stored together in ordinary landfills. That is creating additional epidemiological and toxicological dangers [10];

- destruction of medical waste which is dangerous in epidemiological and toxicological terms is performed in local hospital boilers and other flawed facilities, and does not provide the necessary hygienic and ecological security;

- staff of medical institutions and patients are not trained to perform the right processing of medical waste;
- lack of necessary instructional and methodological literature, educational visual aids and materials;

Conclusion. In order to develop an effective mechanism for handling medical waste given the requirements of the legislation of the Russian Federation, it is necessary to develop the concept and implement it as a pilot project based on the cluster of the medical and pharmaceutical industry. After implementing this program, it will be possible to calculate the degree of efficiency and to consider the scale of this concept at the regional and federal level.

System for processing medical waste could be a useful instrument for improving the current situation in the environmental sphere and in the sphere of healthcare system as well as for creating additional workplaces.

\section{REFERENCES}

1. Medical Waste Management and Disposal, Noyes Data Corporation, 1991.

2. Alex E.S. Green. Medical Waste Incineration and Pollution Prevention, 2013.

3. Frank L. Cross, Jr., Howard D. Hesketh. Engineering Medical Waste-to-Energy Systems, 2012.

4. Diane Heminway, Anne Rabe. Managing medical waste, 1992.

5. Carl A. Zimring,William L. Rathje. Encyclopedia of Consumption and Waste: The Social Science of Garbage, 2010.

6. John Burke Sullivan,Gary R. Krieger. Clinical Environmental Health and Toxic Exposures, 1999.
7. Startsev A.A.., Lubarskaya M.A. Rokovodstvo po upravleniu othodami. SPb.: IUNIDO, 2007. $77 \mathrm{~s}$. (rus)

8. Hospital Waste Management and Its Monitoring, Sanskriti Sharma, 2007.

9. Medical, Municipal and Plastic Waste Management Handbook, Niir Board Of Consultants \& Engineers, 2006.

10. Environmental Treatment Technologies for Hazardous and Medical Waste, Subijoy Dutta, 2013.

11. Federal law of 21.11.2011 no. 323-FZ (ed. from 03.07.2016) «About bases of health protection of citizens in the Russian Federation». (rus) 
12. URL: http://www.conserve-energy-future.com /medical-waste-disposal.php

13. URL: http://www.medlit.ru/journalsview/gigsan /view/journal/en/2014/issue-6/608-approaches-of-euro pean-and-russian-legislation-in-the-field-of-managem ent-of-medical-waste/

14. URL: http://www.sharpsdisposal.com/what-ismedical-waste/

15. URL: https://www.cdph.ca.gov/certlic/medica lwaste/Pages/default.aspx

\section{СПИСОК ЛИТЕРАТУРЫ}

1. Medical Waste Management and Disposal, Noyes Data Corporation, 1991.

2. Alex E.S. Green. Medical Waste Incineration and Pollution Prevention, 2013.

3. Frank L. Cross, Jr., Howard D. Hesketh. Engineering Medical Waste-to-Energy Systems, 2012.

4. Diane Heminway, Anne Rabe. Managing medical waste, 1992.

5. Carl A. Zimring,William L. Rathje. Encyclopedia of Consumption and Waste: The Social Science of Garbage, 2010.

6. John Burke Sullivan, Gary R. Krieger. Clinical Environmental Health and Toxic Exposures, 1999.

7. Старцев А.А., Любарская М.А Руководство по управлению отходами. СПб.: ЮНИДО, 2007. 77 с.

8. Hospital Waste Management and Its Monitoring, Sanskriti Sharma, 2007.
9. Medical, Municipal and Plastic Waste Management Handbook, Niir Board Of Consultants \& Engineers, 2006.

10. Environmental Treatment Technologies for Hazardous and Medical Waste, Subijoy Dutta, 2013.

11. Об основах охраны здоровья граждан в Российской Федерации : Федер. закон № 323-Ф3 от 21.11.2011 г. (ред. от 03.07.2016 г.).

12. URL: http://www.conserve-energy-future.com /medical-waste-disposal.php

13. URL: http://www.medlit.ru/journalsview/gigs an/view/journal/en/2014/issue-6/608-approaches-of-eu ropean-and-russian-legislation-in-the-field-of-manage ment-of-medical-waste/

14. URL: http://www.sharpsdisposal.com/what-ismedical-waste/

15. URL: https://www.cdph.ca.gov/certlic/medic alwaste/Pages/default.aspx

MOVCHAN Konstantin S. - Deputy director for international raltions in «XXI century. Medical and pharmaceutical projects». Master of science in material flow management.

191024. Nevsky av. 146. Lit. A. St. Petersburg. Russia. Tel.: 8(812)240-35-55.

МОВЧАН Константин - заместитель директора по международным отношениям «Союза в сфере обращения лекарственных средств и медицинской техники. Медико-фармацевтические проекты XXI век». Магистр по специальности «Управление материальными потоками».

191024, Невский пр., д. 146, лит. А, Санкт-Петербург, Россия. Тел.: 8(812)240-35-55. 